\title{
A FIRST SURVEY OF METAZOAN PARASITES IN THE FISHES OF LAKE POWELL, UTAH
}

\author{
Aaron M. Brooksby1,3, Mehmet Cemal Oguz $1,2,4$, and Mark C. Belk ${ }^{1}$
}

\begin{abstract}
Aвstract.-Lake Powell (Colorado River drainage, Utah and Arizona, USA) is an important and unique fishery comprising several nonnative fishes. There are no previous studies of the parasites of the fishes of Lake Powell. We provide a general survey of the metazoan parasites found in the numerically dominant fish species of the reservoir. We collected and surveyed for parasites in 236 fishes of 8 species. We found 832 parasites comprising 13 species. All of the parasite species we found are widespread throughout North America and other parts of the world. Six of the 13 species of parasites we found have been documented previously in the Colorado River system. In general, benthic-feeding fishes exhibited higher parasite richness and intensity compared to pelagic-feeding fishes. This study serves as a baseline for parasite community studies in Lake Powell and can provide a comparison for future studies.
\end{abstract}

Resumen.-El lago Powell (drenaje del río Colorado, Utah y Arizona, EE.UU.) es una pesquería única e importante compuesta por varios peces no nativos. No hay estudios previos sobre los parásitos de los peces del lago Powell. Proporcionamos un estudio general de los parásitos metazoarios encontrados en las especies de peces numéricamente dominantes de la reserva. Colectamos y estudiamos los parásitos de 236 peces de 8 especies. Encontramos 832 parásitos de 13 especies. Todos los parásitos que encontramos son especies que tienen una distribución amplia en toda América del Norte y en otras partes del mundo. Seis de las trece especies de parásitos han sido documentadas previamente en el sistema del Río Colorado. En general, los peces bentónicos exhibieron mayor riqueza e intensidad de parásitos en comparación con los peces pelágicos. Este trabajo sirve como base para el estudio de las comunidades de parásitos del lago Powell y puede proporcionar una comparación para estudios futuros.

Lake Powell was created in 1963 from the closing of the Glen Canyon Dam on the Colorado River (National Academy of Sciences 1991). It has become a renowned destination for recreational water sports and is considered an exceptional fishery. Nonnative sport fishes dominate the fish fauna of Lake Powell (Maxwell and Thoesen 1965). To effectively manage this system, it is essential to understand the ecological context and ecological interactions of the fishes. Parasites are an important, yet often overlooked, component of the ecology of fishes (Williams et al. 1992, Poulin 1999). Parasite surveys have been published for the Lower Colorado River (Linder et al. 2012) and Little Colorado River (Choudhury et al. 2004, Stone et al. 2007) below Lake Powell; however, there has been no parasite survey for the fishes of Lake Powell.

Parasite occurrence in a given community is determined by presence of appropriate hosts and opportunity for immigration and colonization. However, few consistent patterns exist for community assembly of parasites of freshwater fishes, making it difficult to predict the expected assemblage of parasites in a wholly nonnative community of fishes, such as that found in Lake Powell (Price and Clancy 1983, Kennedy and Bush 1994, Poulin 1996, 1997). To document diversity and abundance of fish parasites in Lake Powell and the distribution of fish parasites among fish species, we surveyed for metazoan parasites in numerically dominant fish species in 2 separate years.

\section{Methods}

We surveyed for parasites in April of 2013 and 2015. In 2013, we sampled fishes near Wahweap Bay (36.99768, -111.477110; Lone Rock Canyon, Warm Creek Bay, Gunsight Bay, Antelope Creek), and in 2015 we sampled fishes near Bullfrog Bay (37.506614, $-110.724569)$ and the surrounding canyons (Crystal Springs, Forgotten Canyon, and Moqui Canyon). During both sampling periods, we collected fish by using standard hook-and-line practices along with gill nets to supplement

${ }^{1}$ Department of Biology, Brigham Young University, Provo, Utah 84602.

${ }^{2}$ Biology Department, Faculty of Science, Ataturk University, 25240, Erzurum, Turkey.

${ }^{3}$ Corresponding author. E-mail: aaronmbrooksby@gmail.com

${ }^{4}$ Present address: Vice Rector, Artuklu University, 47200, Mardin, Turkey. 


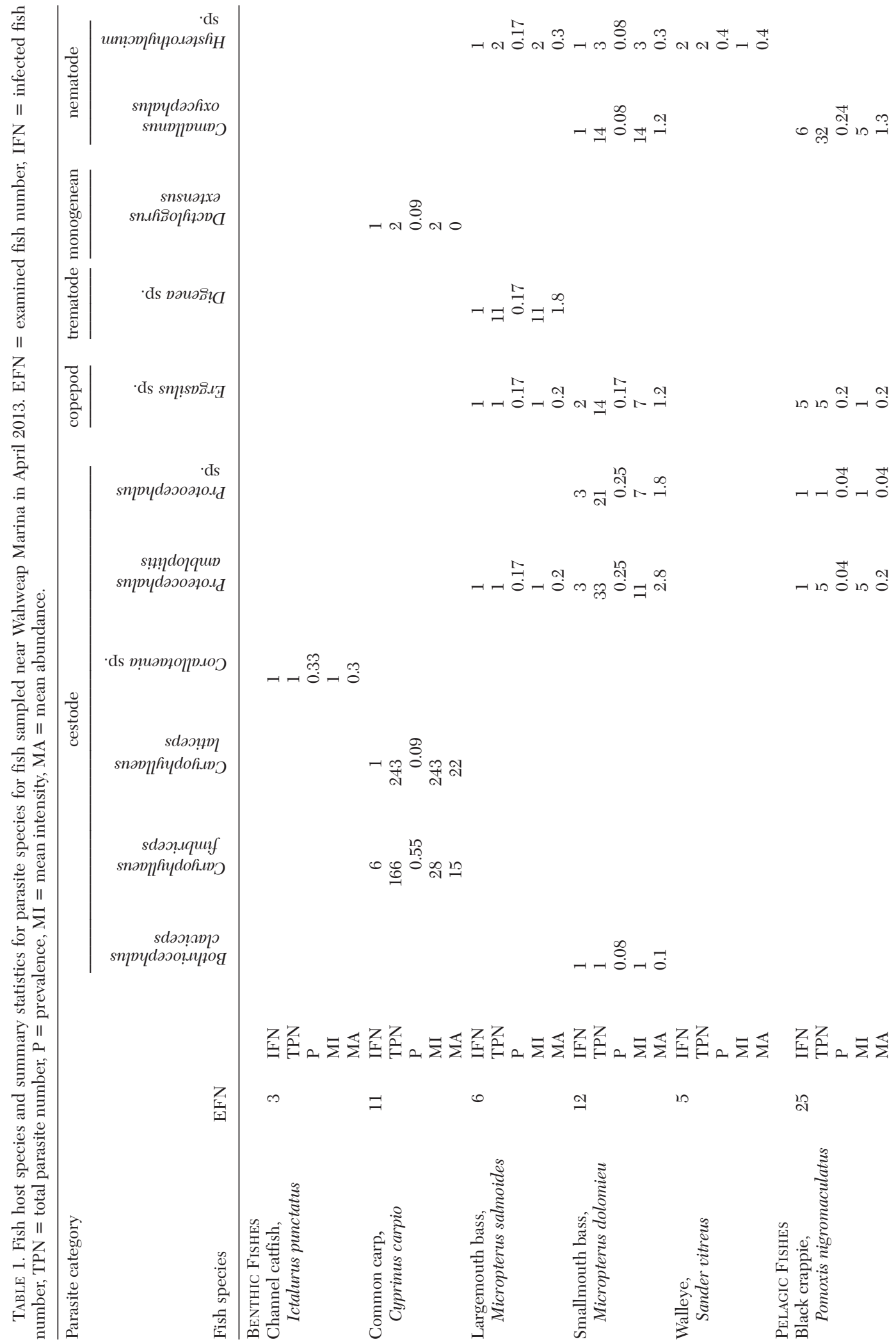




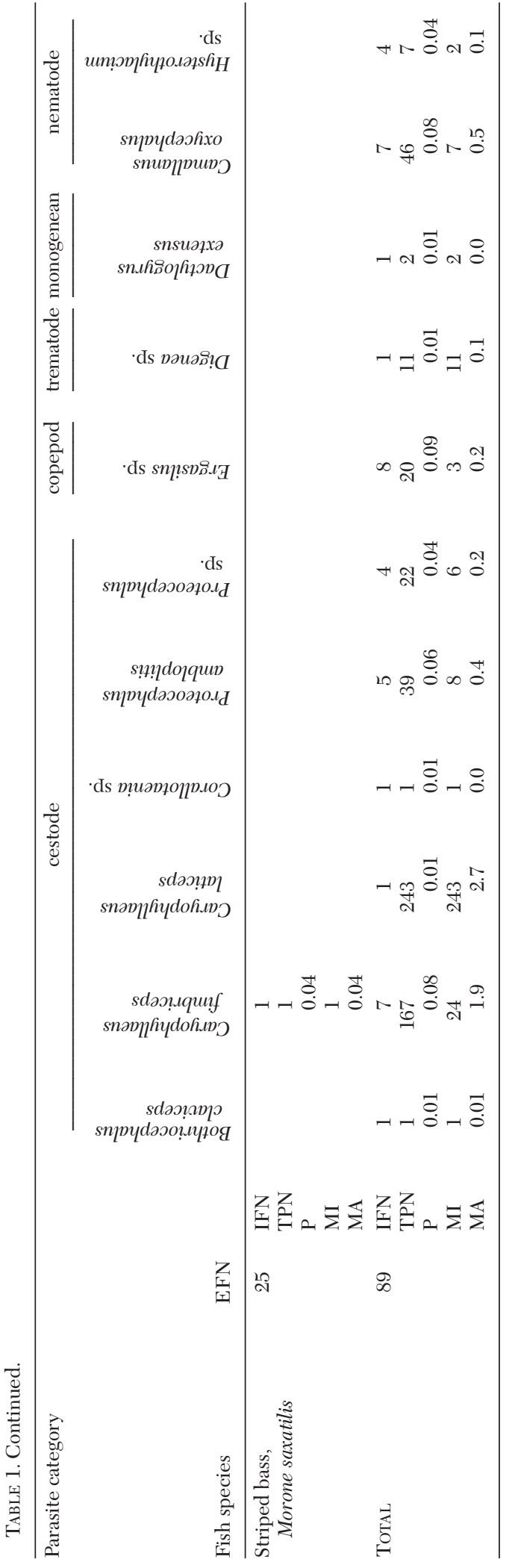

sample sizes. We obtained samples of 10 fish species as noted in Table 1.

We caught and dissected fishes on-site to ensure the collection of live parasites. We used standard techniques as described by Pritchard and Kruse (1982). We employed stereomicroscopes and examined all internal organs, gills, and body surfaces for metazoan parasites. We temporarily preserved cestodes, monogeneans, and digeneans found in the gastrointestinal tract and liver by placing individuals on a slide glass with a drop of alcohol-formalin-acetic acid (AFA), covering them with slide covers, and wrapping nylon twine around the whole slide. We then stored the slides in jars of $70 \%$ ethyl alcohol for transportation to the lab for staining and identification. Nematodes and copepods were preserved in individual test tubes filled with 70\% ethyl alcohol.

We stained cestodes, monogeneans, and digeneans in the lab using Mayer's carmalum staining mixture (Pritchard and Kruse 1982) and then created permanent slides of each species using Canada balsam. We left nematodes and copepods whole and unstained in vials of $70 \%$ alcohol. We identified parasites to the genus level and to the species level when possible using taxonomic keys and descriptions in Hunter (1927), Schmidt (1970) Gardener and Schmidt (1986), Oros et al. (2010), Hoffman (1999), Fagerholm (1982), La Rue (1914), and Essex (1928).

We then calculated prevalence, mean intensity, and mean abundance for each parasite species (Bush et al. 1997). Prevalence was calculated as the number of fish of a given species infected by a parasite of a given species divided by the total number of fish examined of that species. Mean intensity was calculated as the number of total parasites found of a given species divided by the number of infected fish of a given species. Mean abundance was calculated as the number of total parasites of a given species divided by the total number of fish examined of a given species. Parasite richness is defined as the number of different species found in a single host or single fish species. We did not include fish species for which fewer than 10 individuals were examined (i.e., Lepomis cyanellus and Dorosoma petenense). Although our focus was on internal parasites, we did find one leach (Family Hirudinidae) attached to the pelvic fin of one channel catfish (Ictalurus punctatus). Voucher 
specimens of all parasites were deposited in the H.W. Manter Laboratory of Parasitology at the University of Nebraska State Museum, University of Nebraska, Lincoln, Nebraska, USA (Appendix 1).

\section{RESUlTS}

Fish

In 2013, we examined 87 fishes of 7 species, all nonnative (the term nonnative refers to species that are not natively found in the Colorado River system). Black crappie (Pomoxis nigromaculatus) and striped bass (Morone saxatilis) were the most numerous; each made up $28.7 \%$ of the total number of fishes sampled. Smallmouth bass (Micropterus dolomieu) exhibited the highest parasite richness, with 6 species of metazoan parasites found among sampled fish. Common carp (Cyprinus carpio) exhibited the highest average intensity of infection, with one individual infected with 243 parasites of one species (Table 1 ).

In 2015, we examined 149 fishes of 8 species, all nonnative. Gizzard shad (Dorosoma cepedianum) made up $26.2 \%$ of the total sample, with smallmouth bass, striped bass, and walleye (Sander vitreus) each making up another $18.1 \%$ of the total sample. Channel catfish exhibited the highest parasite richness, with 4 species of parasite found among the sampled fish. Common carp exhibited the highest average intensity of infection, with one individual infected with 57 parasites of one species (Table 2).

Combining both sampling years, we collected and examined 236 individual fish of 8 nonnative species which encompassed all of the numerically dominant fish species in the reservoir. In general, benthic- and nearshorefeeding fishes exhibited higher parasite richness and intensity compared to pelagic-feeding fishes. Striped bass made up $22 \%$ of the total sampled fish. Channel catfish exhibited the highest prevalence of parasites. Common carp exhibited the highest average intensity of infection. Striped bass exhibited the lowest prevalence of parasites. Walleye and striped bass exhibited the lowest average intensity of infection. Parasite richness was highest in smallmouth bass, which exhibited 6 different species of metazoan parasites, followed by largemouth bass (Micropterus salmoides), black crappie, channel catfish, and common carp, each infected by 4 parasite species. The lowest parasite richness was found in striped bass and walleye, each infected by 1 species, followed by gizzard shad infected by 2 species (Table 3 ).

\section{Parasites}

In 2013, we found 559 individual parasites comprising 11 species. These included cestodes, copepods, trematodes, monogeneans, and nematodes. Six species of cestode made up $84.6 \%$ of the total number sampled in 2013 (Table 1). Ergasilus sp. exhibited the highest prevalence and Caryophyllaeus laticeps exhibited the highest mean abundance (Table 1).

In 2015, we found 273 individual parasites comprising 4 species of cestode and 1 nematode. Cestodes made up $89.4 \%$ of the total parasites examined. Proteocephalus ambloplitis exhibited the highest prevalence. Corallobothrium fimbriatum and Khawia sp. exhibited the highest mean abundances (Table 2).

For both sampling years combined, we found a total of 832 individual parasites in adult, larva, and metacercaria stages comprising 13 different species (Table 3). Proteocephalus ambloplitis was the most prevalent parasite, infecting 26 individuals among 5 species of fish. Caryophyllaeus laticeps, a cestode, had the highest mean intensity; however, all 243 individuals were found within a single common carp. Five species of parasites were found in only one species of fish (Table 3).

\section{Discussion}

We found substantially different numbers and types of parasites in the 2 different locations and years. In the 2013 sample, we found 166 Caryophyllaeus fimbriceps infecting 6 of the common carp sampled (Table 1). In the 2015 sample we did not find any C. fimbriceps; however, we only collected 3 common carp that year compared to the 11 collected in 2013 (Table 2). Similarly, we found 72 Corallobothrium fimbriatum infecting 8 of the channel catfish sampled in 2015, but none of the channel catfish collected in 2013 exhibited infection from $C$. fimbriatum. There was a large discrepancy in channel catfish sample sizes between the 2 years: 16 in 2015 and only 3 in 2013. These and other similar results are likely due to sampling variation, especially for relatively rare parasite species. It could also be that there are spatial or temporal variations among 
TABLE 2. Fish host species and summary statistics for parasite species from fish sampled near Bullfrog Marina in April 2015. $\mathrm{EFN}=$ examined fish number, $\mathrm{IFN}=$ infected fish number, $\mathrm{TPN}=$ total parasite number, $\mathrm{P}=$ prevalence, $\mathrm{MI}=$ mean intensity, MA = mean abundance.

\begin{tabular}{|c|c|c|c|c|c|c|c|}
\hline \multicolumn{3}{|l|}{ Parasite category } & \multicolumn{4}{|c|}{ cestode } & \multirow[b]{2}{*}{ 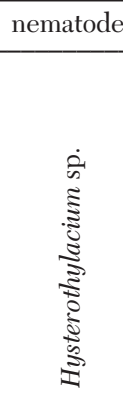 } \\
\hline Fish species & EFN & & 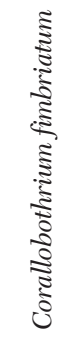 & 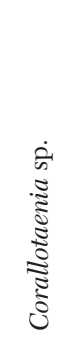 & 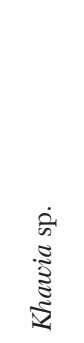 & 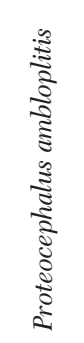 & \\
\hline Benthic Fishes & & & & & & & \\
\hline Channel catfish, Ictalurus punctatus & 16 & $\begin{array}{l}\text { IFN } \\
\text { TPN } \\
\text { P } \\
\text { MI } \\
\text { MA }\end{array}$ & $\begin{array}{l}8 \\
72 \\
0.5 \\
9 \\
4.5\end{array}$ & $\begin{array}{c}3 \\
46 \\
0.19 \\
15 \\
2.9\end{array}$ & $\begin{array}{c}1 \\
23 \\
0.06 \\
23 \\
14\end{array}$ & $\begin{array}{l}7 \\
13 \\
0.44 \\
2 \\
0.8\end{array}$ & \\
\hline Common carp, Cyprinus carpio & 3 & $\begin{array}{l}\text { IFN } \\
\text { TPN } \\
\text { P } \\
\text { MI } \\
\text { MA }\end{array}$ & & & $\begin{array}{c}1 \\
57 \\
0.33 \\
57 \\
19\end{array}$ & & \\
\hline Largemouth bass, Micropterus salmoides & 5 & $\begin{array}{l}\text { IFN } \\
\text { TPN } \\
\text { P } \\
\text { MI } \\
\text { MA }\end{array}$ & & & & $\begin{array}{c}2 \\
10 \\
0.4 \\
5 \\
2\end{array}$ & $\begin{array}{l}1 \\
4 \\
0.2 \\
4 \\
0.8\end{array}$ \\
\hline Smallmouth bass, Micropterus dolomieu & 27 & $\begin{array}{l}\text { IFN } \\
\text { TPN } \\
\text { P } \\
\text { MI } \\
\text { MA }\end{array}$ & & & & $\begin{array}{l}11 \\
18 \\
0.41 \\
1.6 \\
0.7\end{array}$ & $\begin{array}{l}11 \\
25 \\
0.41 \\
2.3 \\
0.9\end{array}$ \\
\hline Walleye, Sander vitreus & 27 & $\begin{array}{l}\text { IFN } \\
\text { TPN } \\
\text { P } \\
\text { MI } \\
\text { MA }\end{array}$ & & & & & \\
\hline \multicolumn{8}{|l|}{ Pelagic Fishes } \\
\hline Black crappie, Pomoxis nigromaculatus & 5 & $\begin{array}{l}\text { IFN } \\
\text { TPN } \\
\text { P } \\
\text { MI } \\
\text { MA }\end{array}$ & & & & & \\
\hline Gizzard shad, Dorosoma cepedinanum & 39 & $\begin{array}{l}\text { IFN } \\
\text { TPN } \\
\text { P } \\
\text { MI } \\
\text { MA }\end{array}$ & & $\begin{array}{l}1 \\
2 \\
0.03 \\
2 \\
0.05\end{array}$ & & $\begin{array}{l}1 \\
3 \\
0.03 \\
3 \\
0.08\end{array}$ & \\
\hline Striped bass, Morone saxatilis & 27 & $\begin{array}{l}\text { IFN } \\
\text { TPN } \\
\text { P } \\
\text { MI } \\
\text { MA }\end{array}$ & & & & & \\
\hline TOTAL & 151 & $\begin{array}{l}\text { IFN } \\
\text { TPN } \\
\text { P } \\
\text { MI } \\
\text { MA }\end{array}$ & $\begin{array}{c}8 \\
72 \\
0.05 \\
9.0 \\
0.5\end{array}$ & $\begin{array}{c}4 \\
48 \\
0.03 \\
12.0 \\
0.3\end{array}$ & $\begin{array}{c}2 \\
80 \\
0.01 \\
40.0 \\
0.5\end{array}$ & $\begin{array}{l}21 \\
44 \\
0.14 \\
2 \\
0.3\end{array}$ & $\begin{array}{c}12 \\
29 \\
0.08 \\
2.4 \\
0.2\end{array}$ \\
\hline
\end{tabular}




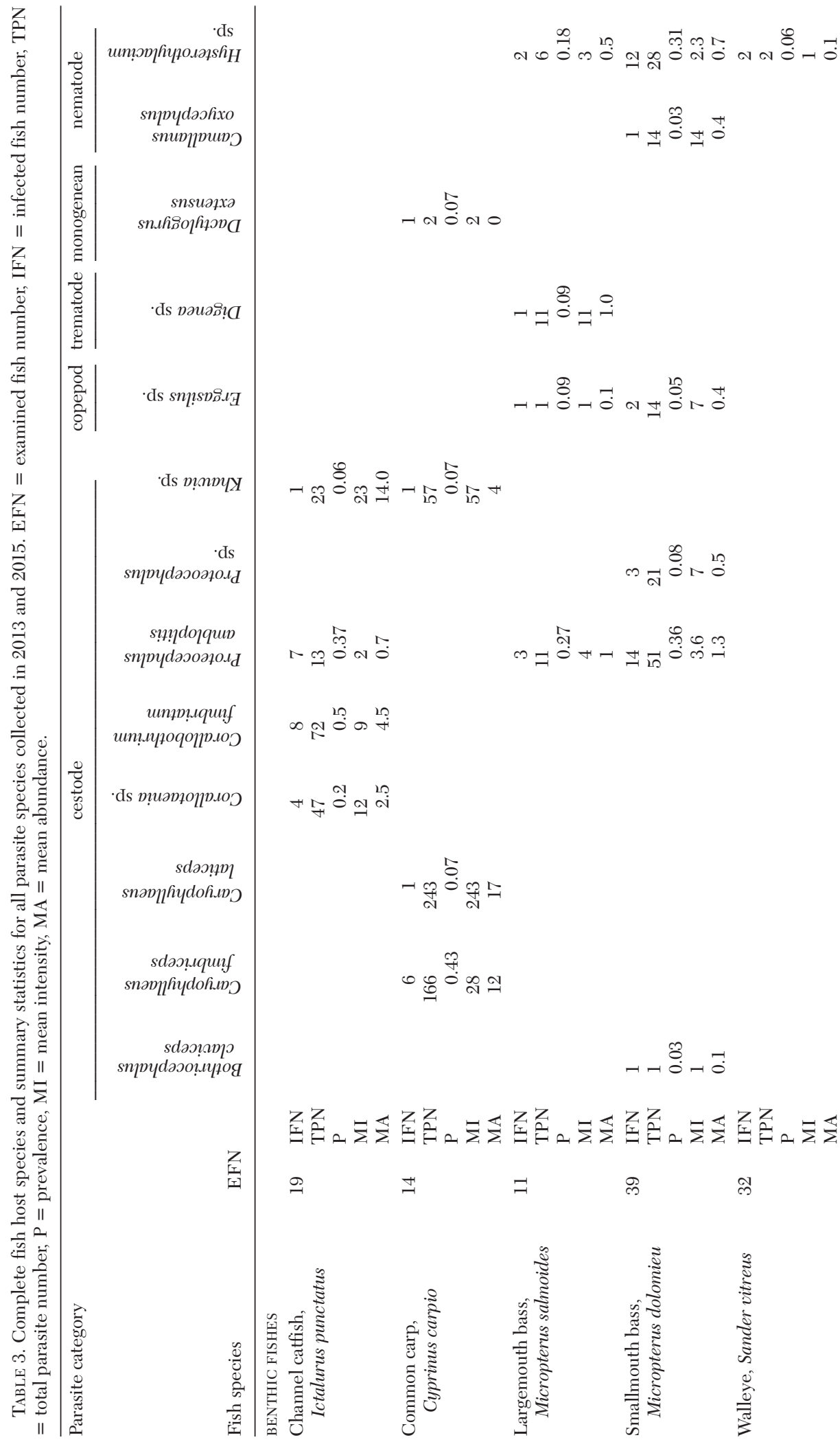




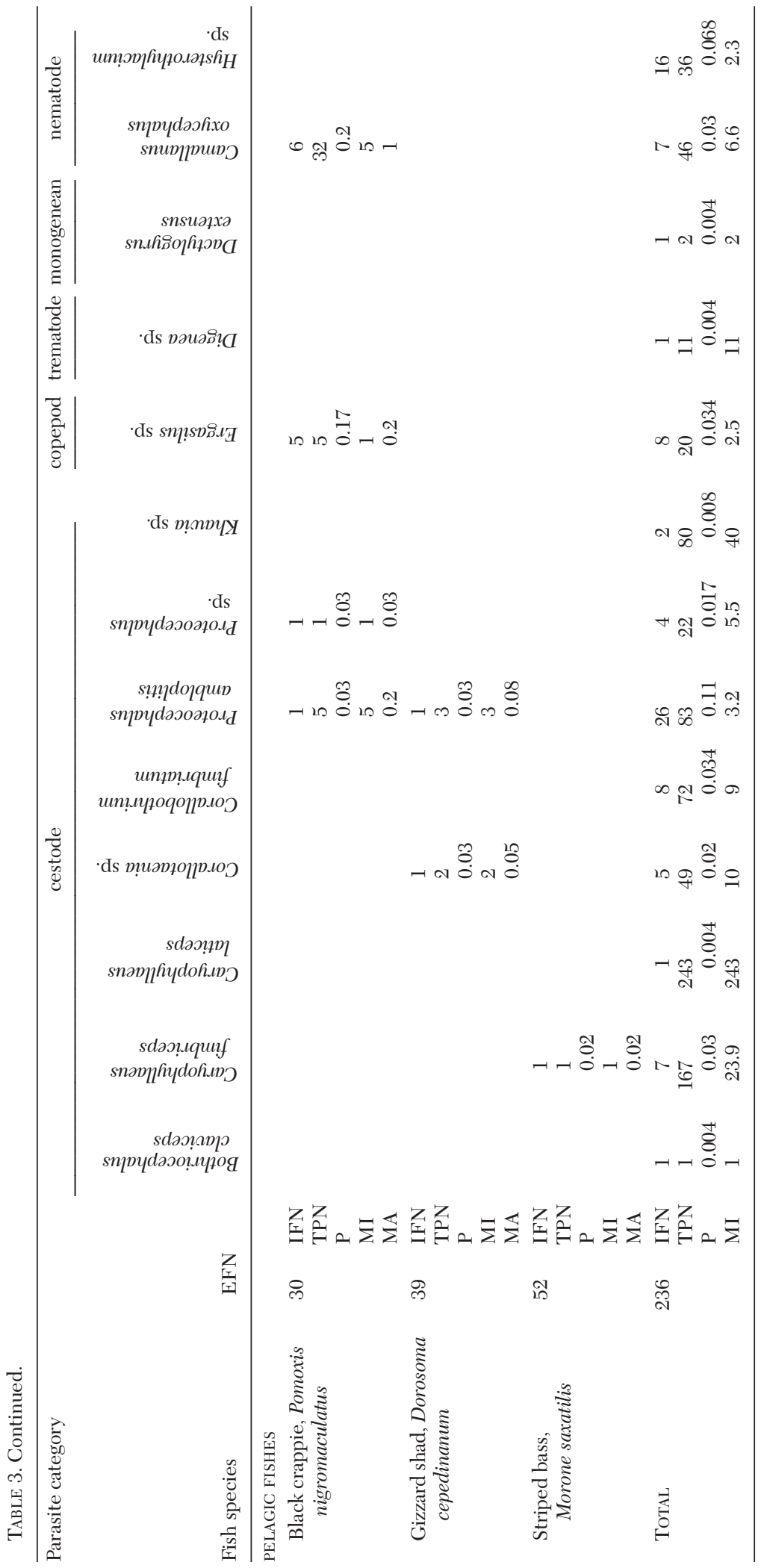


parasite communities throughout the lake that account for the differences between the 2 sampling years. Two out of the 5 walleye sampled in 2013 were infected with Hysterothylacium sp., but there were no infections of any species of metazoan parasite in the 27 walleye sampled in 2015. It is possible that parasite numbers of Hysterothylacium were greater in 2013 compared to 2015 , or it could be that Hysterothylacium does not occur uplake near Bullfrog. This phenomenon was also seen with Camallanus oxycephalus, which was present in one year's sample and completely absent in the other. Temporal variation and seasonal patterns of infection have been observed among other parasites in the Colorado River (Choudhury et al. 2004), which could explain these differences, although further sampling is needed to verify this hypothesis. Based on the differences we saw between the 2 sampling years, there is a high likelihood that other undetected parasites exist in the system at low levels. This study serves as a baseline for future comparison.

In contrast to the spatial and temporal variation observed, one consistent pattern between years was the overall lack of parasite infections in striped bass. Compared to our other species samples, we had a relatively large sample size of striped bass-25 in 2013 and 27 in 2015. Out of the 52 total fish, we found only one infected striped bass, which exhibited only one C. fimbriceps individual (Table 3). Though it is possible that we missed some of the rarer parasite species or sampled only healthy fish due to sampling variation, our data suggest that striped bass are generally parasite-free.

Parasite surveys conducted downstream of Lake Powell provide comparison to the patterns we observed. Surveys below the Glen Canyon Dam report Dactylogyrus extensus infecting common carp, Corallobothrium fimbriatum infecting channel catfish and striped bass, and a species of Ergasilus infecting channel catfish (Choudhury et al. 2004, Linder et al. 2012). Though we also found $D$. extensus infecting common carp, we did not find Ergasilus sp. infecting any channel catfish, nor did we find C. fimbriatum infecting striped bass. Other major differences between our survey and the surveys completed on the Lower Colorado River include the species of fish that were sampled. We only surveyed nonnative species, of which Choudhury et al. (2004) only sampled 2 (common carp and channel catfish) and
Linder et al. (2012) only sampled 3 (channel catfish, common carp, and striped bass). Linder et al. (2012) found a species of Caryophyllidea infecting a native cyprinid, flannelmouth sucker (Catostomus latipinnis), whereas we found Caryophyllaeus laticeps infecting a nonnative cyprinid, common carp.

One of the major differences in the findings of our survey and previous surveys downstream was the absence of Asian tapeworm (Bothriocephalus acheilognathi) in Lake Powell. There is ample evidence of Asian tapeworm infecting native and nonnative cyprinids in the Lower Colorado River (Choudhury et al. 2004, Stone et al. 2007, Linder et al. 2012) and throughout waters across the American Southwest (Archdeacon et al. 2010). Asian tapeworm was introduced to North America through imported grass carp (Ctenopharyngodon idella) and is most commonly found infecting cyprinids (Diaz-Castaneda et al. 1995). In April 2013 and 2015, there was no evidence of Asian tapeworm in our samples. We may not have found any evidence of Asian tapeworm because of our relatively small sample size of cyprinids (14 common carp). However, Asian tapeworm has been recorded infecting a variety of fishes other than cyprinids in the Lower Colorado River (i.e., Ictaluridae, Fundulidae, Salmonidae; Choudhury et al. 2004), which suggests that if Asian tapeworm is present in Lake Powell, it is likely at low levels.

Although parasites have been shown to cause changes in fish behavior and to affect fishes negatively overall (Barber et al. 2000, Barber 2007, Horton and Okamura 2001), we found no cases where parasites appeared to affect fish health negatively. The majority of sampled fishes were infected with few parasites. Even in cases of severely infected fishes, like the common carp sampled in 2013 that was infected with 243 C. laticeps (Table 1), the relative volumes of parasites compared to the volumes of the relatively large-bodied fishes they infected were not substantial. As described in other parasite surveys, the collection methods we employed likely selected for fitter individuals that are less parasitized. Individuals that are highly parasitized are less likely to be actively moving and feeding, or are doing so at a decreased rate. If parasites are more prevalent among younger age classes, sampling methods similar to ours that target older and larger fishes are more likely to miss 
individuals that are more highly infected (Linder et al. 2012).

Parasites observed in the fishes of Lake Powell exhibit similar life histories with slight variations in host specialization. The majority of observed parasites are cestodes that are transmitted via invertebrates to their definitive hosts. Caryophyllaeus laticeps and Caryophyllaeus fimbriceps are multihost, trophically transmitted cestodes that infect tubificid worms as larvae. When a benthic-foraging fish feeds on the worm, the fish becomes the definitive host for the parasite and the place where the parasite will reach maturity and reproduce, expelling eggs into the digestive tract and out into the water column (Kulakovskaya 1962, Bauer et al. 1969, Anderson 1976, Lumsden et al. 1982). These 2 parasites are found throughout Europe and North America (Hunter 1927, Chubb et al. 1982), and generally infect cyprinids. Khawia spp., Bothriocephalus claviceps, Corallotaenia sp., Corallobothrium fimbriatum, and Proteocephalus ambloplitis are cestodes with multiple hosts that have a strategy similar to other cestodes of releasing eggs into the water column. However, these species specialize in exploiting copepods as intermediate hosts, as opposed to annelids (Bangham 1925, 1928, Essex 1927, Hunter 1928, 1930, Hunter and Hunter 1929, Larsh 1941, Befus and Freeman 1973, Stromberg and Crites 1974, 1975, Brandt et al. 1981, Scholz 1997). All of these cestodes have been reported in multiple locations throughout North America, and they appear to be generalist parasites in habitat and in host fish species (Hare 1943, Bangham and Vernard 1946, Morrison 1957, Wilson 1957, Harms 1960, Anthony 1963, Becker 1967, Spall 1968, Becker and Houghton 1969, Woods 1971, Rubertone and Hall 1975, Baker and Crites 1976, Amin 1978, 1991, Sutherland and Holloway 1979, McReynolds and Webster 1980, Williams and Sutherland 1981, Hoffnagle et al. 1990, McDonald and Margolis 1995, Amin and Minckley 1996, Hoffman 1999, Scholz et al. 2001, Szmygiel and Reyda 2010, McAllister and Bursey 2011, Rosas-Valdez and Perez-Ponce de Leon 2011, Scholz et al. 2011). Digenea sp. (metacercaria) are multihost trematodes that are transmitted to their definitive host through mollusc intermediate hosts (Ginetsinskaya 1988). Digenea have previously been described in Micropterus salmoides in the United States (Becker and
Houghton 1969). Camallanus oxycephalus, a nematode, is a multihost parasite that uses copepods as an intermediate host. It is a generalist parasite and has been described throughout North America (Bangham 1941, Becker and Houghton 1969, Aho et al. 1991, McDonald and Margolis 1995, Hoffman 1999, cf. Zhang 2012). The life history of Hysterothylacium sp., another nematode, is similar to that of other species already noted, but the species is more of a generalist in terms of its intermediate host choice, using annelids, molluscs, echinoderms, crustaceans, and other fish species (Fagerholm 1982, Anderson 2000, Rohde 2005). With its broader intermediate host capabilities, Hysterothylacium sp. is also capable of infecting a broad range of top predatory fishes as definitive hosts and it occurs worldwide (Hare 1943, Meyers 1978, Fagerholm 1982). Dactylogyrus extensus, a monogenean, has a direct life cycle that does not require an intermediate host. It relies solely on a definitive fish host to complete its life cycle. Eggs are released directly into the water column where they hatch. Larvae then wait for a fish to inhale them where they attach themselves to the gill filaments of the host fish. After attachment on a suitable host, larvae mature and begin reproducing (Izyumova and Zelentsov 1969, Dawes 1977). Dactylogyrus extensus has been described only in common carp in North America (Fantham and Porter 1948, Haderlie 1953, Mizelle and Klucka 1953, Bangham 1955, Roberts 1957, Hoffman 1967). Ergasilus sp. is part of a small group of ectoparasitic copepods that also have direct life cycles. Ergasilus sp., often referred to as gill louse, is capable of prolonged periods of free swimming before attaching itself to the body or gills of the host fish (Freyer 1969, Abdelhalim et al. 1991). These parasites are non-host-specific, but have been described among centrarchids in North America and Great Britain (Roberts 1965, Freyer 1969).

Benthic-feeding fishes showed higher prevalence and intensity of parasite infections than pelagic-feeding species. On average, each species of benthic-feeding fish was infected by 3.8 species of parasites, whereas each species of pelagic-feeding fish was infected by only 2.3 species of parasites. Mean intensity of parasite infections was 21.1 for benthic-feeding fishes and 2.2 for pelagic-feeding fishes. These differences are consistent between years and 
locations and are unlikely to be due to differences in sample sizes. Using our results as a baseline, future parasite surveys can compare parasite infections among fishes to gain insights into changes occurring among fish communities over time and throughout the lake.

\section{ACKNOWLEDGMENTS}

We thank the Utah Division of Wildlife Resources (UDWR) along with the Biology Department at Brigham Young University for supporting this study. Specifically, we thank Wayne Gustaveson, Richard Hepworth, and Mike Hadley from UDWR, and the numerous undergraduate students, who all helped collect fish. We also thank Anna Forest who helped with parasite dissection and identification in 2013. All fish were collected under the direction of the UDWR.

\section{Literature Cited}

AbDelhalim, A.I., J.W. Lewis, AND G.A. Boxshall. 1991. The life-cycle of Ergasilus sieboldi Nordmann (Copepoda: Poecilostomatoida), parasitic on British freshwater fish. Journal of Natural History 25:559-582.

Aho, J.M., A.O. Bush, and R.W. Wolfe. 1991. Helminth parasites of bowfin (Amia calva) from South Carolina. Journal of the Helminthological Society of Washington 58:171-175.

Amin, O.M. 1978. Intestinal helminths of some Nile fishes near Cairo, Egypt with redescriptions of Camallanus kirandensis Baylis 1928 (Nematoda) and Bothriocephalus aegyptiacus Ryšavý and Moravec 1975 (Cestoda). Journal of Parasitology (1978):93-101.

Amin, O.M. 1991. Helminth parasites from some Tichigan Lake fishes in southeast Wisconsin. Journal of the Helminthological Society of Washington 58:255-260.

Amin, O.M., AND W.L. MincKLEY. 1996. Parasites of some fish introduced into an Arizona reservoir, with notes on introductions. Helminthological Society of Washington 63:193-200.

ANDERSON, R.C. 2000. Nematode parasites of vertebrates: their development and transmission. CAB Publishing, Wallingford. Page 635.

ANDERson, R.M. 1976. Dynamic aspects of parasite population ecology. Ecological Aspects of Parasitology. North-Holland Publishers, Amsterdam, The Netherlands. Pages 431-462.

Anthony, J.D. 1963. Parasites of eastern Wisconsin fishes. Wisconsin Academy of Science, Arts and Letters 52:83-95.

Archdeacon, T.P., A. Iles, J.S. Kline, and S.A. Bonar. 2010. Asian fish tapeworm Bothriocephalus acheilognathi in the desert southwestern United States. Journal of Aquatic Animal Health 22:274-279.

BAKER, J.C., AND J.L. Crites. 1976. Parasites of channel catfish Ictalurus punctatus Rafinesque, from the island region of western Lake Erie. Proceedings of the Helminthological Society of Washington 43: 37-39.
Bangham, R.V. 1925. Study of the cestode parasites of the black bass in Ohio, with special reference to their life history and distribution. Ohio Journal of Science 25:255-270.

Bangham, R.V. 1928. Life history of the bass cestode Proteocephalus ambloplitis. Transactions of the American Fisheries Society 1927:206-208.

Bangham, R.V. 1941. Parasites from fish of Buckeye Lake, Ohio. Ohio Journal of Science 41:441-448.

Bangham, R.V. 1955. Studies on fish parasites of Lake Huron and Manitoulin Island. American Midland Naturalist 53:184-194.

Bangham, R.V., And C.E. Venard. 1946. Pages 33-46 in Parasites of fish of Algonquin Park lakes. Series Publications of the Ontario Fisheries Research Laboratory, No. 65, University of Toronto Studies. Biological Series 53 (Studies on Algonquin Park). University of Toronto Press, Toronto, Ontario, Canada.

Barber, I. 2007. Parasites, behaviour and welfare in fish. Applied Animal Behaviour Science 104:251-264.

Barber, I., D. Hoare, and J. Krause. 2000. Effects of parasites on fish behaviour: a review and evolutionary perspective. Reviews in Fish Biology and Fisheries 10:131-165.

Bauer, O.N., V.A. Musselius, and Y.A. Strelkov. 1969. Diseases of pond fishes. Publishing Kolos, Moscow. Page 220. [In Russian].

BeckeR, C.D. 1967. The parasitic fauna of teleosts in six Washington lakes. Northwest Science 41:160-198.

Becker, D.A., ANd W.C. Houghton. 1969. A survey of the helminth parasites of selected game fishes of Lake Fort Smith, Arkansas. Arkansas Academy of Science Proceedings 23:110-117.

Befus, A.D., And R.S. Freeman. 1973. Life cycles of two corallobothriin cestodes (Proteocephaloidea) from Algonquin Park, Ontario. Canadian Journal of Zoology 51:249-257.

Brand, F.D.W., J.G. Van As, H.J. Schoombee, and V.L. Hamilton-ATTwell. 1981. The occurrence and treatment of Bothriocephalosis in the common carp, Cyprinus carpio in fish ponds with notes on its presence in the largemouth yellowfish Barbus kimbeyerlensis from the Vall Dam, Transvaal. Water SA 7:35-42.

Bush, A.O., K.D. LafFerTy, J.M. LotZ, and A.W. Shostak. 1997. Parasitology meets ecology on its own terms: Margolis et. al. revisited. Journal of Parasitology 83:575-583.

Choudhury, A., T.L. Hoffnagle, And R.A. Cole. 2004. Parasites of native and nonnative fishes of the Little Colorado River, Grand Canyon, Arizona. Journal of Parasitology 90:1042-1053.

Chubb, J.C., W.H.R. Lumsden, R. Muller, and J.R. BAKER. 1982. Seasonal occurrence of helminths in freshwater fishes. Part IV. Adult Cestoda, Nematoda and Acanthocephala. Advances in Parasitology 20: $1-292$.

Dawes, B. 1977. Advances in parasitology. Volume 15. United States edition. Academic Press Inc., New York, NY. Page 385.

Diaz-Castaneda, V., A. Carabez-Trejo, and R. LamotheARGumedo. 1995. Ultrastructure of the pseudophyllidean cestode Bothriocephalus acheilognathi, parasite of freshwater fish of commercial importance. Anales del Instituto de Biologia, Universidad Nacional Autónoma de México, Serie Zoologia 66:1-16.

Essex, H.E. 1927. The structure and development of Corallobothrium. Journal of Parasitology 14:130-131. 
Essex, H.E. 1928. The structure and development of Corallobothrium with descriptions of two new fish tapeworms. Illinois Biological Monographs. Volume 11. University of Illinois, Urbana, IL.

Fagerholm, H.P. 1982. Parasites of fish in Finland. VI. Nematodes. English, illustrated edition. Page 128.

Fantham, H.B., AND A. Porter. 1948. The parasitic fauna of vertebrates in certain Canadian fresh waters, with some remarks on their ecology, structure and importance. Proceedings of the Zoological Society 117: 609-649.

Freyer, G. 1969. The parasitic copepod Ergasilus sieboldi Nordmann, new to Britain. Naturalist 909:51.

Gardner, S.L., AND G.D. SchmidT. 1986. Two new species of Litomosoides (Nematoda: Onchocercidae) from pocket gophers (Rodentia: Geomyidae) in Colorado. Systematic Parasitology 8:235-242.

GinetsinskaYa, T.A. 1988. Trematodes, their life-cycles, biology and evolution. Amerind Publishing Co. Pvt. Ltd., New Delhi, India.

Haderlie, E.C. 1953. Parasites of the fresh-water fishes of northern California. University of California Publications in Zoology 57:303-440.

HaRe, R.C. 1943. An ecological study of the worm parasites of Portage Lakes fishes. Ohio Journal of Science 43:201-208.

Harms, C.E. 1960. Some parasites of catfishes from Kansas. Journal of Parasitology 46:695-701.

Hoffman, G.L. 1967. Parasites of North American freshwater fishes. University of California Press, Berkeley and Los Angeles, CA. 486 pp.

Hoffman, G.L. 1999. Parasites of Northern American freshwater fishes. Cornell University Press, Ithaca, NY. 539 pp.

Hoffnagle, T.L., R.A. Cole, and W.L. Shoop. 1990. Gastrointestinal parasites of the blue catfish (Ictalurus furcatus) in Kentucky Lake, Tennessee. Helminthological Society of Washington 57:40-43.

Horton, T., and B. OKamura. 2001. Cymothoid isopod parasites in aquaculture: a review and case study of a Turkish sea bass (Dicentrarchus labrax) and sea bream (Sparus auratus) farm. Diseases of Aquatic Organisms 46:181-188.

Hunter, G.W. 1927. Notes on the Caryophyllaeidae of North America. Journal of Parasitology 14:16-26.

Hunter, G.W. 1928. Contributions to the life history of Proteocephalus ambloplitis (Leidy). Journal of Parasitology 14:229-243.

Hunter, G.W., III. 1930. Studies on the parasites of fishes of the Lake Champlain watershed. Suppl. 19th Ann. Rept. New York State Conserv. Dept., Biol. Surv. Lake Champlain Watershed (1929):241-260.

Hunter, G.W., III., AND W.S. Hunter. 1929. Further experimental studies on the bass tape-worm Proteocephalus ambloplitis (Leidy). Suppl. 18th Ann. Rept. New York State Conserv. Dept., Biol. Surv. Erie Niatara System (1928):198-207.

Izyumova, N.A., AND N.I. Zelentsov. 1969. Observations on the development of Dactylogyrus extensus (Muller and Cleave, 1932). Parazitologiya 3:528-531. [In Russian].

Kennedy, C.R., And A.O. Bush. 1994. The relationship between pattern and scale in parasite communities: a stranger in a strange land. Parasitology 109: 187-196.

Kulakovskaya, O.P. 1962. Problems of the ecology of some species of Caryophyllidae (cestoda) under con- ditions of carp fishery in western region of Ukraine. Voprosy ekologii paraziticheskikh organizmov i entomofagov, 5:73-74. [In Russian].

Larsh, J.E., JR. 1941. Corallobothrium parvum n. sp., a cestode from the common bullhead, Ameiurus nebulosus Le Sueur. Journal of Parasitology 27:221-227.

LA RuE, G.R. 1914. A revision of the cestode family. Illinois Biological Monograph, Volume 1. University of Illinois, Urbana, IL. Page 319.

Linder, C.M., R.A. Cole, T.L. Hoffnagle, B. Persons, A. Choudhury, R. Haro, and M. Sterner. 2012. Parasites of fishes in the Colorado River and selected tributaries in Grand Canyon, Arizona. Journal of Parasitology 98:117-127.

Lumsden, W.H.R., R. Muller, and J.R. Baker. 1982. Advances in Parasitology 20:1-503.

Maxwell, J.M., and R.W. Thoesen. 1965. Lake Powell stocking story. Progressive Fish-Culturist 27:115-120.

McAllister, C.T., And C.R. Bursey. 2011. Corallotaenia parva (Cestoidea: Proteocephalidae) from the Black Bullhead, Ameiurus melas (Siluriformes: Ictaluridae) in southeastern Oklahoma. Proceedings of the Oklahoma Academy of Science 91:29-30.

McDonald, T.E., and L. Margolis. 1995. Synopsis of the parasites of fishes of Canada. National Research Council of Canada.

McReynolds, M., AND J.D. Webster. 1980. Parasites of the yellow bass from two southern Indiana lakes. Proceedings of the Indiana Academy of Sciences 89:154-158.

Meyers, T.R. 1978. Prevalence of fish parasitism in Raritan Bay, New Jersey. Proceedings of the Helminthological Society of Washington 45:120-128.

Mizelle, J.D., AND A.R. KLUCKA. 1953. Studies on monogenetic trematodes. XIV. Dactylogryridae from Wisconsin fishes. American Midland Naturalist 49: 720-733.

Morrison, G.R. 1957. The incidence and distribution of the bass tapeworm Proteocephalus ambloplitis in southern New Hampshire waters. Technical Circular No. 13, Dingell-Johnson Project F-8-R. Management and Research Division of the New Hampshire Fish and Game Department. 33 pp.

National ACademy of Sciences. 1991. Colorado River ecology and dam management. National Academies Press, Washington, DC. Page 276.

Oros, M., T. Scholz, V. Hanzelová, and J.S. Mackiewicz. 2010. Scolex morphology of monozoic cestodes (Caryophyllidea) from the Palaearctic Region: a useful tool for species identification. Folia Parasitolo Gica 57: 37-46. [In Czech].

Poulin, R. 1996. Richness, nestedness, and randomness in parasite infracommunity structure. Oecologia 105:545-551.

Poulin, R. 1997. Species richness of parasite assemblages: evolution and patterns. Annual Review of Ecology and Systematics 28:341-358.

Poulin, R. 1999. The functional importance of parasites in animal communities: many roles at many levels? International Journal for Parasitology 29:903-914.

Price, P.W., and K.M. Clancy. 1983. Patterns in number of helminth parasite species in freshwater fishes. Journal of Parasitology 69:449-454.

Pritchard, M.H., and G.O.W. Kruse. 1982. The collection and preservation of animal parasites. Technical Bulletin No 1. University of Nebraska Press, Lincoln, NE. Page 141. 
Roberts, L.S. 1957. Parasites of the carp, Cyprinus carpio L. in Lake Texoma, Oklahoma. Journal of Parasitology 43:54.

RoberTs, L.S. 1965. Ergasilus tenax sp. n. (Copepoda: Cyclopoida) from the white crappie, Pomoxis annularis Rafinesque. Journal of Parasitology 51:987-989.

RoHDE, K. 2005. Marine parasitology. CSIRO Publishing, Melbourne, and CABI Publishing, Wallingford, Oxon. Page 565.

Rosas-Valdez, R., and G. Perez-Ponce de Leon. 2011. Patterns of host specificity among the helminth parasite fauna of freshwater siluriforms: testing the biogeographical core parasite fauna hypothesis. Journal of Parasitology 97:361-363.

Rubertone, J.A., and J.E. Hall. 1975. A survey of fish parasites from the Greenbrier River. Proceedings of the Helminthological Society of Washington 42: $58-59$.

SchmidT, G.D. 1970. How to know the tapeworms. C. Brown Company Publishers, Dubuque, IA.

Scholz, T. 1997. Life-cycle of Bothriocephalus claviceps, a specific parasite of eels. Journal of Helminthology 71:241-248.

Scholz, T., J. Brabec, I. Kráová-Hromadová, M. Oros, E. Bazsalovicsová, A. Ermolenko, and V. Hanzelová. 2011. Revision of Khawia spp. (Cestoda: Caryophyllidea), parasites of cyprinid fish, including a key to their identification and molecular phylogeny. Folia Parasitologica 58:197-223. [In Czech].

Scholz, T., T. Shimazu, P.D. Olson, and K. Nagasawa. 2001. Caryophyllidean tapeworms (Platyhelminthes: Eucestoda) from freshwater fishes in Japan. Folia Parasitologica 48:275-288. [In Czech].

SpaLL, R.D. 1968. The endoparasitic helminths of fishes from Lake Carl Blackwell, Oklahoma. Proceedings of the Oklahoma Academy of Science 49:91-99.

Stone, D.M., D.R. Van Haverbeke, D.L. Ward, and T.A. HunT. 2007. Dispersal of nonnative fishes and parasites in the intermittent Little Colorado River, Arizona. Southwestern Naturalist 52:130-137.

APPENDIX 1. Accession numbers for metazoan parasites collected from the fishes of Lake Powell, Utah, USA, and deposited at the University of Nebraska State Museum, Parasitology Collection.

\begin{tabular}{ll}
\hline Taxon & Accession number \\
\hline Bothriocephalus claviceps & HWML 103056 \\
Camallanus oxycephalusi & HWML 99863 \\
Caryophyllaeus fimbriceps & HWML 103054 \\
Caryophyllaeus laticeps & HWML 103053 \\
Corallobothrium fimbriatum & HWML 103058 \\
Corallotaenia & HWML 103057 \\
Dactylogyrus extensus & HWML 103061 \\
Digenea & HWML 103060 \\
Ergasilus & HWML 99865 \\
Hysterothylacium & HWML 99864 \\
Khawia & HWML 103055 \\
Proteocephalus & HWML 103063 \\
Proteocephalus ambloplitis & HWML 103059 \\
Proteocephalus ambloplitis & HWML 103062 \\
\hline
\end{tabular}

Stromberg, P.C., And J.L. Crites. 1974. The life cycle and development of Camallanus oxycephalus Ward and Magath, 1916 (Nematoda: Camallanidae). Journal of Parasitology 60:117-124.

Stromberg, P.C., And J.L. Crites. 1975. An analysis of the changes in the prevalence of Camallanus oxycephalus (Nematoda: Camallanidae) in western Lake Erie. Ohio Journal of Science 75:117-124.

Sutherland, D.R., and H.L. Holloway JR. 1979. Parasites of fish from the Missouri, James, Sheyenne, and Wild Rice Rivers in North Dakota. Proceedings of the Helminthological Society of Washington 46: $128-134$.

Szmygiel, C., AND F.B. Reyda. 2010. A survey of the parasites of smallmouth bass (Micropterus dolomieu). 43rd Annual Report of the Suny Oneonta Biological Field Station. Pages 235-240.

Williams, D.D., AND D.R. Sutherland. 1981. Khawia sinensis (Caryophyllidea: Lytocestidae) from Cyprinus carpio in North America. Proceedings of the Helminthological Society of Washington 48:253-255.

Williams, H.H., K. MacKenzie, and A.M. McCarthy. 1992. Parasites as biological indicators of the population biology, migrations, diet, and phylogenetics of fish. Reviews in Fish Biology and Fisheries 2: 144-176.

WILSON, W.D. 1957. Parasites of fishes, Leavenworth County State Lake. Transactions of the Kansas Academy of Science 60:393-399.

Woods, C.E. 1971. Helminth parasites of fishes from the Forest River, North Dakota. American Midland Naturalist 86:212-215.

Zhang, K. 2012. The parasite release hypothesis and the success of invasive fish in New Zealand. Master's thesis, University of Waikato, New Zealand. 180 pp.

Received 14 June 2016

Accepted 6 December 2016

Published online 15 March 2017 